\title{
THE PERSONNEL MANAGER AS A MENTAL HEALTH PROFESSIONAL: SOME POSSIBLE AREAS OF INVOLVEMENT
}

\author{
J. BERNATH \\ DEPARTMENT OF PSYCHOLOGY \\ UNIVERSITY OF THE WITWATERSRAND
}

\begin{abstract}
OPSOMMING
In hierdie artikel, word 'n saak uitgemaak vir die Personeelbestuurder in handel-en nywerheidsorganisasies as iemand wat 'n belangrike rol het om te vervul as 'n geestesgesondheidspraktisyn. Dit word beweer dat tot 25 persent van alle werknemers in 'n organisasie aan geestesafwykings ly wat hulle oneffektief maak in die uitvoering van hul pligte. Die skrywer handhaaf die standpunt dat die Personeelbestuurder kan help om die aantal werknemers wat so geaffekteer is te verminder deur aandag te gee aan sake soos welsyn, opvoeding en rehabilitasieprogramme. Dit sal geestesgesondheid verbeter en ' $n$ meer produktiewe arbeidsmag tot gevolg hê.
\end{abstract}

The role of the personnel manager in industry and commerce is often seen in terms merely of enhancing production and work efficiency by selecting the right man for the job. This role includes close liaison with heads of production departments, who view the personnel department as a "supply line" in terms of manpower procurement. While not denying that this is indeed an important function of the personnel department, it is perhaps unfortunate that so many businessmen see this as the only role of the personnel manager. This article will describe some other spheres of activity in which the personnel manager can and should involve himself -- spheres which are regarded as important in fostering the mental health of company employees and providing a stable work force.

The suggestion that the personnel manager function as a mental health professional will probably be unacceptable to many people. Yet if we regard the organization as a microcosm of society, as it has been described by organizational theorists e.g. Schein (1965) then the suggestion has some validity. Schein $(1965$, p.9) has defined the organization as "... the rational coordination of the activities of a number of people for the achievement of some common explicit purpose or goal, through division of labour and function, and through a hierarchy of authority and responsibility" (own emphasis). As it became increasingly clear 
that the key variable in organizational efficiency is people, so psychologists and later, personnel managers, were drawn into the field. Industrial psychologists liaised with engineers to analyze the basic characteristics of work so that each individual worker could be given a job which maximized (i) this human capabilities and limits, (ii) coordination and teamwork among employees, and (iii) overall efficiency. According to Schein (1965), the main psychological problem which presented itself to the psychologists was: how can organizational policies or social practices be developed which will permit the integration of human needs and organizational demands?

Now, it is fairly widely recognized that one of the roles of the mental health professional (especially the community psychologist) is the development and teaching of behaviour which will permit the successful integration of human needs and organizational demands is analogous to that of the community psychologist. In fact, the profession of personnel management may be regarded as a psychological profession.

In recognizing this fact, there are various areas of involvement for the personnel manager which present itself.

\section{PRIMARY PREVENTION OF MENTAL DISORDER}

Caplan (1964, p.33) has defined the concept primary prevention as follows: "Primary prevention does not seek to prevent a specific person from becoming sick ... it seeks to reduce the risk for a whole population". Applied to business and industry, primary prevention would entail pinpointing working conditions which cause mental stress, and endeavouring to restructure these conditions before the symptoms of stress appear. Where personnel managers have in the past concerned themselves with the mental health of employees, they have directed their efforts mainly at amelioration, rehabilitation and secondary prevention. While commendable and certainly of benefit to the workers, it is nevertheless worthwhile noting that these are relatively short-term projects and goals. The only really adequate goal is one of primary prevention which tackles the problem at its roots and eradicates the causes instead of treating the effects.

In commerce and industry, it is the personnel manager who is the most suitably equipped to deal with this problem. Many possess background training in the behavioural sciences and thus have an understanding of individual needs and of what constitutes a mental health risk. This understanding, plus the personnel manager's knowledge of organizational 
systems in commerce and industry enable him to determine those situations where the individual's psychological needs are subjugated by those in industry. The personnel manager should be aware that the global work situation (i.e. working conditions salaries, power and status positions, etc.) contains the primary factors involved in individual mental disorders and it is inappropriate (if not self-defeating) to focus on the worker's internal dynamics and ignore other real problem areas. Kiesler (in Denner and Price, 1973) has stated the problem quite succinctly: "We cannot afford to delude ourselves into thinking that better patient care will be sufficient answer for the mental health problems of communities. Until we find out how to bring about actual reduction in the number of casualties of all kinds in the population, we will only have begun to scratch the surface of our mental health problems".

What is envisaged is a personnel function which includes programmes concerned with welfare, education, rehabilitation of mental patients, and gerontology. Each of these areas will be briefly dealt with.

\section{WELFARE}

Worker welfare is seen as the creation of a working environment free of mental stressors. If, for example, a personnel manager maintains that large industrial assembly line production is a negative contributing factor to mental health and that this needs alteration and re-designing, he should take it upon himself to advocate the necessary changes. Because such a change may require huge investments, time and effort, this is no reason to disregard such change. In a thought provoking article entitled "On the Quality of Working Life", ChichesterClark (1973, p. 27) has observed that "we cannot hope to run industry and commerce indefinitely on the basis of individuals doing repetitive, boring, and even soul-destroying tasks". He points out that this creates stresses which lead to absence, labour turnover and problems in the use of manpower resources - all of which are major contributors to decreased productivity. There is every reason to think that money spent on improving the quality of working life is money well spent. Chichester (Op.cit., p.27) mooted that "for my part the most compelling argument for asking British industry and commerce to take job satisfaction seriously is not such theoretical considerations as the incompatibilities between modern technology and workers' expectations, or even of alienation from work in the shape of such things as turnover and reject rates. It is to be found in the forty or fifty well-documented cases of change in work or work organization introduced in this country (England) and abroad 
which have shown that job satisfaction can be increased -- in the sense that the workers concerned at least prefer the new methods and would not revert to the old -- while at the same time, productive efficiency can be maintained or improved".

These changes took years to introduce and involved some hard bargaining on the part of management. But there is enough hard evidence to warrant an effort to speed up the publication of knowledge about what has been, and is being done and achieved. For example, Saab-Scania replaced the straight line or final assembly with teams bases on autonomous assembly groups; and Philips has been experimenting with autonomous groups instead of television set assembly lines.

We have come a long way since the days when women and children crawled through the water and dirt of mine pits dragging coal carts. There is, however, much that can still be done in the way of making environments free of mental stresses and strains.

\section{EDUCATION}

Scheer (1970) has pointed out that this is the first generation in which our earlier schooling is no longer sufficient to carry us through life. Formal education received years ago is no guarantee that we can meet successfully the demands of modern living. New skills, ideas and attitudes are needed to cope successfully with a growing, ever-changing environment. Low-level workers may want to broaden their educational backgrounds while executives may want to participate in non-job related development programmes.

By "education" is meant not merely classroom activities, but rather more general selfdevelopment activity. Often what is taught in the classroom at school is irrelevant to the requirements of society and the world of work. Postman and Weingartner (1971) have made the point that there is clearly no more important function for education to fulfil than that of helping people to recognize the world they actually live in and simultaneously of helping them to master concepts that will increase their ability to cope with it.

Adult education can definitely fulfil a need and the personnel manager is in the best position to evaluate the needs of the different employees, and to initiate adult education programmes. In terms of productivity, the company can only prosper by providing the means whereby its employees can develop their potential and learn to cope better with the demands of our society. 
It has been said that the rehabilitation of the mental patients is complete only when he is holding a job and earning a salary. Many mental patients are casualties of the present industrial environment. Perhaps industry and commerce own it to these people to reassimilate them and give them a helping hand. The personnel manager can assist in the placement of these people by matching their skills with the demands of certain jobs and providing a feedback counselling service for the new employees, a service which has been found to the vital in rebuilding the ex-patient's self-confidence.

A flexible, open-minded approach is needed here and the personnel manager, with his background training in the behavioural sciences, is in a good position to supervise such a program, which would probably entail encouraging attitudinal changes in other employees.

\section{GERONTOLOGY}

Gerontology, or the study of the aged, is a branch of medicine to which increased attention is being given. Retirement is a time of crisis for many people, as their self-image has been determined largely by their occupational roles. Once this prop falls away, it is difficult to maintain a positive identity.

People should be prepared for retirement, and should be made aware of the problems which they will encounter, so that potential crises may be avoided. What is envisaged is a preretirement program, with the worker gradually being phased out of his job, instead of the "here today, gone tomorrow" system at present in operation. A phase-out system could extent over a year, with the worker spending a decreasing amount of time at work each month (and correspondingly, more leisure time at home). Productivity need not suffer, as the worker can use this year to train the man who will take over his job. Salary can be drawn in proportionate amounts from the company and from the pension fund. Such a system would help the worker adapt to an increasing amount of leisure time and during this pre-retirement program, he may discuss with the personnel manager any problem he foresees or encounters.

In this way, the personnel manager could make a vital contribution to the much neglected problem of old age.

What have been outlined above are a few areas where the personnel manager can use his expertise in promoting mental health among company employees. According to Kisker 
(1972), mental health is industry's most costly health problem. He has estimated that emotional disturbances and personality problems add up to about a ten billion dollar loss to American business and industry each year. One mental health expert reported that "from 20 to 25 percent of all employees in every corporation or industrial unit are suffering from mental disorders. They range from psychoses to industrial maladjustment, manifested in absenteeism, accidents, dissatisfaction, alcoholism, turnover, and poor job performance" (Sheer, 1970).

Primary prevention aims not to cure this 25 percent, but at creating a healthier work environment to cut down on this number. There are many businessmen who will question whether industry and commerce can afford to introduce the changes and policies envisaged in this paper. This writer would like to turn this question around and ask these businessmen whether commerce and industry can afford not to involve itself in the mental health problems of its employees. Can industry afford to have 25 percent of its workers relatively unproductive?

Businessmen must see an interest in the mental health of their employees and the creation of an environment conducive to work as aids to increasing production. Social responsibility, as Feldberg (1975) has pointed out, is not philanthropy, but rather, it is part of the process of ensuring a stable work force for the future, and providing an environment in which business can continue to operate. In the long run, social considerations are seen as having a significant effect on business profits. "The cost of carrying out social responsibilities", says Feldberg, "should be considered as the normal costs of doing business". (Feldberg, 1975, p.11). To this, this writer would like to add that the cost of neglecting the mental health of the worker (this includes the cost of mental treatment for the casualties, accidents and absenteeism at work, turnover, training of new employees resulting from increased turnover, poor job performance, etc.) would seem to outweigh by far the cost of the programmes outlined above.

It has been stated that personnel managers must make a contribution where it counts to the profit at the bottom of the line. I would like to conclude this article by suggesting that by involving himself in the mental well-being of his employees, the personnel manager will make a valuable start to this contribution. 
In this article, it is proposed that the Personnel Manager in commerce and industry has a valuable role to play as a mental health professional. It has been reported that up to 25 percent of all employees in every corporation are suffering from mental disorders which, in some way, make them ineffective in their jobs. By involving himself in areas such as welfare, education and rehabilitation programmes, it is argued that the Personnel Manager can help reduce this number and thus ensure a more psychologically healthy and more productive work force.

\section{REFERENCES}

Caplan, G. Principles of Preventative Psychiatry. Tavistock Publication, 1964.

Chichester-Clark, R. On the quality of working life. Personnel Management, 1973, 5 (11), 2630.

Denner, B. \& Price, R.H. (Eds.) Community Mental Healing: Social Action \& Reaction. New York: Holt, Rinehart \& Winston, 1973.

Feldberg, M. Business profits and social responsibility. People and Profits, 1975, 3(1), 7-11.

Kisker, G. The Disorganized Personality. New York: McGraw-Hill, 1972.

Postman and Weingartner, 1971.

Scheer, W.E. Personnel Director's Handbook. Chicago: The Dartnell Corporation, 1970.

Schein, E.H. Organization Psychology. Englewood Cliffs, N.J.: Prentice Hall, 1965.

Stern, R. Counselling and the Community. Unpublished Paper, U.C.T., 1975. 